\title{
Biological Properties of Chemically Modified Insulins. I. Biological Activity of Proinsulin and Insulin Modified at $\mathbf{A}_{1}$-glycine and $B_{29}$-lysine*
}

\author{
R. H. Jones, D. I. Dron, M. J. Ellis, P. H. Sönksen and D. Brandenburg \\ Department of Medicine, St. Thomas' Hospital Medical School, London, and Deutsches Wollforschungsinstitut, Aachen, Federal Republic \\ of Germany
}

Summary. Beef insulin, pork proinsulin and four derivatives of beef insulin modified at the $A_{1}-B_{29}$ site on the molecular surface have been studied. Three derivatives had a synthetic crosslink between the $A$ and B chains. Previous studies with these materials [2, 3 and 5] had demonstrated in vivo bioactivities which were much higher than those displayed in vitro. This paper reports experiments which explain this discrepancy. The analogues were administered at equimolar rates to anaesthetised greyhounds by a priming-dose constant infusion technique and the plasma concentrations achieved were estimated by radioimmunoassay. Proinsulin and the modified insulins were metabolised more slowly than insulin. Biopotency values, which related fall in plasma glucose concentration to the total administered dose of analogue, agreed broadly with published results of conventional in vivo bioassays. On the other hand, calculation of potency in relation to the serum concentration of analogue actually achieved, yielded results which agreed more closely with in vitro assay data. We conclude that for these analogues, reported discrepancies between in vitro and in vivo biopotencies can be largely explained by the different rates at which these materials are metabolised.

Key words: Insulin structure-function, chemically modified insulin, proinsulin, bioactivity of insulin analogues.

With the increasing availability of specifically chemically modified insulins it is now becoming possible to study in detail structure-function relationships of the

* Dedicated to Professor H. Zahn on the occasion of his 60 th birthday molecule. By studying the way in which a change in structure at a known site of the molecule alters its bioactivity, attempts are made to define those characteristics of the structure of insulin which are essential for its activity. Ideally it is hoped to identify an active site on the molecular surface; a site which is involved in binding to the insulin receptor on the target cell.

One group of analogues on which there is already a considerable body of information comprises those with a chemical modification of the $\mathrm{N}$ terminal glycine of the insulin A chain and of the $\varepsilon$ amino group of $\mathrm{B}_{29}$ lysine, two groups which lie in close spatial proximity, (Blundell et al. [1]).

Freychet et al. [2], have examined some of these materials for their capacity to displace radio-iodinated insulin from isolated liver cell membranes and expressed this as a percentage of that of insulin. Gliemann and Gammeltoft [3] and Gliemann and Sørensen [4] have derived similar results by examining the ability of the analogues to displace labelled insulin from isolated fat cells, and also by studying lipogenesis in the same preparation. Brandenburg, Puls et al. [5] examined the biological activity of these materials by following the fall in plasma glucose concentration after bolus injection in the rabbit, and Lazarus et al. [6] studied proinsulin in a similar way in the rat. Thus Freychet and Gliemann have expressed potency in relation to the concentration of the analogue in the medium surrounding the biological preparation while Brandenburg et al. and Lazarus et al. expressed their results in relation to the total dose administered to the intact animal. The former methods have all given results which are significantly lower than the latter for all the materials we have studied and this is also generally true for other modifications at the $A_{1} B_{29}$ site in the insulin molecule (Blundell et al. [7]).

A possible explanation for this observation is that modifications at that site impair not only the biological 

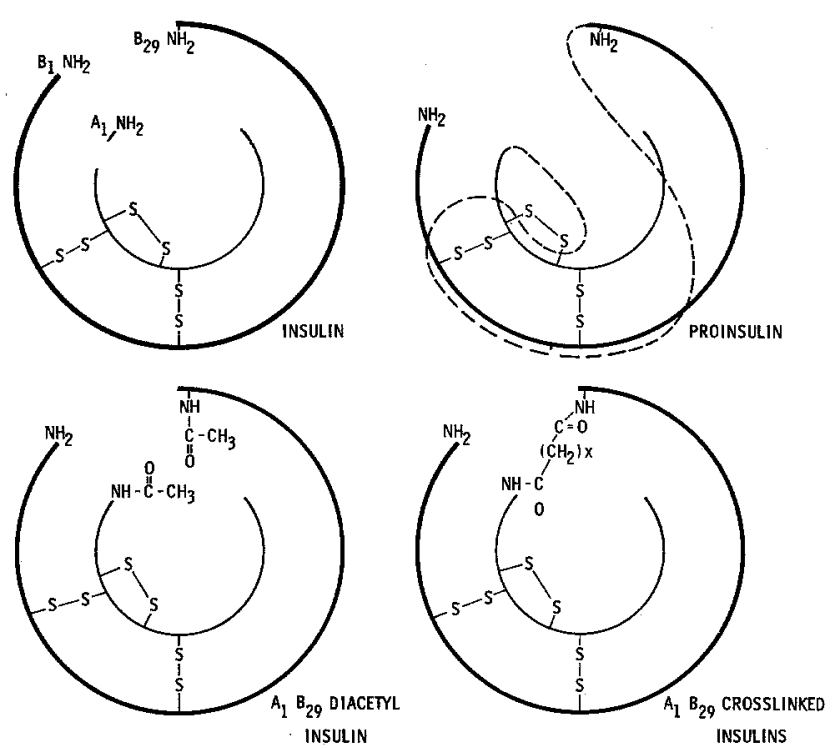

Fig. 1. Diagrammatic representation of insulin, proinsulin, and the chemically modified materials studied. The crosslinked analogues have an aliphatic link between the free amino groups of $A_{1}$ glycine and $B_{29}$ lysine. $A_{1}, B_{29}$ diacetyl insulin has no synthetic crosslink, but the free amino groups are chemically modified in a comparable fashion

effectiveness of insulin but also reduce its susceptibility to degradation. If this were the case administration of these materials to an animal would result in higher concentrations in the plasma and at the receptor site than would be achieved with equimolar doses of insulin.

The experiments reported here allow us to test this hypothesis. The fall in plasma glucose concentration during an in vivo experiment can be related to either the dose used or to the serum concentration achieved. We have infused the materials under study at a constant rate, thus achieving a steady state, and have related their hypoglycaemic activity to the concentrations actually present in the plasma. In this way we have simulated the conditions which apply in an in vitro assay. We have also related the fall in plasma glucose concentration to the total dose of material administered during the experiment, a calculation which allows comparison with published conventional in vivo assay data.

The possibility of an in vivo conversion of a relatively inactive analogue to a more active form or to insulin itself also requires consideration, as this would give rise to apparently higher activity in the whole animal than that demonstrable in vitro.

For one of the materials we have studied it was possible to select an insulin antiserum which could distinguish between insulin-like immunoreactivity and analogue-like immunoreactivity in the plasma. We have thereby been able to test this suggestion.

\section{Materials and Methods}

Bovine insulin, pork proinsulin and four semisynthetic analogues of beef insulin were studied. These were $A_{1}$, $\mathbf{B}_{29}$ diacetyl insulin and three crosslinked materials of the form. $\mathrm{A}_{1}$ Gly-NH-CO- $\left(\mathrm{CH}_{2}\right)_{\mathrm{x}}-\mathrm{CO}-\mathrm{NH}-\mathrm{B}_{29}$ Lys. ie. $A_{1}-B_{29}$ oxalyl insulin $x=0 ; A_{1}-B_{29}$ suberoyl insulin $x=6 ; A_{1}-B_{29}$ dodecoly insulin $x=10$. These materials were prepared in Aachen from crystalline beef insulin (Brunnengräber Lübeck $24 \mathrm{U} / \mathrm{mg}$ ) as described by Brandenburg $[5,8,9]$ and shown to be homogeneous by electrophoresis and other techniques. The pork proinsulin was obtained from Dr. Schlichtkrull, Novo Research Laboratories, Copenhagen.

\section{Experimental Protocol}

Experiments consisted of the administration of each material to intact anaesthetised greyhounds by a priming-dose constant infusion technique similar to that previously used in man (Sönksen et al. [11]). The animals were studied after an overnight fast. Anaesthesia was induced by intravenous Pentobarbitone ( 30 $\mathrm{mg} / \mathrm{kg}$ body weight) and the animals maintained on intermittent positive pressure ventilation with air to achieve an end-expiratory $\mathrm{CO}_{2}$ concentration between $4-5 \%$ as measured by an infra-red $\mathrm{CO}_{2}$ analyser.

Blood samples were obtained from a plastic cannula in the external jugular vein. The material under study, dissolved in isotonic saline with $1 \%$ human serum albumin was infused into a hind-limb vein, the rate of infusion being accurately controlled by a slow infusion púmp. 1 to $1^{1 / 2} \mathrm{~L}$ of isotonic saline were also infused during each experiment to maintain an adequate diuresis, and urine was collected via an indwelling urethral catheter. Each experiment lasted $4 \frac{1}{2} \mathrm{~h}$ and was divided into five periods of $30 \mathrm{~min}$ and a final period of $90 \mathrm{~min}$. The first period [1] was used for baseline sampling. During the following four periods (II-V) graded infusions of insulin or analogue were administered, the rate being doubled every $30 \mathrm{~min}$. The infusion was stopped at the beginning of the final period (VI). The priming-doses given at the beginning of each infusion period were calculated assuming a distribution space of approximately $10 \%$ of body weight. Dilutions of the insulin, insulin analogues, and proinsulin were adjusted to give equimolar infusion rates per $\mathrm{kg}$ body weight. Blood samples were taken at $10 \mathrm{~min}$ intervals throughout the experiment except during period VI when samples were taken every minute for the first ten minutes, every five minutes for the next twenty minutes, every ten minutes for the next thirty minutes and every fifteen minutes for the final 
$1 / 2 \mathrm{~h}$. Urine from each period was collected separately and aliquots taken. The experimental protocol is illustrated in Figure 2.

Nine experiments were conducted with beef insulin, six with pork proinsulin, seven with $\mathrm{A}_{1}, \mathrm{~B}_{29}$ diacetyl insulin and with $A_{1}-B_{29}$ dodecoyl insulin, five with $A_{1}-B_{29}$ oxalyl insulin, and three with $A_{1}-B_{29}$ suberoyl insulin.

\section{Assay Methods}

Plasma glucose was estimated with a Beckman glucose analyser using a glucose oxidase method.

Immuno-reactive serum insulin-like material was assayed by the double antibody method described by Morgan and Lazarow 1963 [10] as modified by Sönksen et al. [11], except that charcoal-treated dog serum was used in place of human serum. Human monocomponent insulin (Novo) was iodinated with ${ }^{125} \mathrm{I}$ by a chloramine $\mathrm{T}$ method (Greenwood, Hunter and Glover [12]) and purified by gel filtration on a G50 sephadex column.

23 antisera to porcine or human insulin and one to porcine proinsulin were initially tested to define the cross-reactivity of the analogues with insulin. Two antisera were selected for use in the assays. The first, (GP5) showed no apparent difference in affinity for insulin, proinsulin or the analogues and gave suitable standard dilution curves for the assay of any of these materials. The second (Ab1) showed higher specificity such that inhibition of $\mathrm{I}^{125}$ insulin binding was less marked with the cross-linked analogues than with insulin, so that non-parallel dilution curves were obtained. GP5 was used to assay serum immunoreactive material in all the experiments, the concentration being read from a standard curve of the relevant analogue. Each assay also included dilutions of the infusion mixture. $\mathrm{Ab} 1$ was used to assay serial dilutions of six serum samples from experiments with $\mathrm{A}_{1}-\mathrm{B}_{29}$ dodecoyl insulin, three from the end of the period of most rapid infusion (V 30) and three collected $60 \mathrm{~min}$ after stopping the infusion (VI 60). In these assays standard curves of both $\mathrm{A}_{1}-\mathrm{B}_{29}$ dodecoyl insulin and beef insulin were included.

\section{Fat Cell Experiments}

The ability of the analogues to stimulate lipogenesis in a preparation of isolated fat cells was compared to that of insulin. Epididymal fat cell suspensions from $100-120 \mathrm{G}$ male Wistar rats were prepared by the method described by Gliemann [12] and their incorporation of ${ }^{3} \mathrm{H}$ from ${ }^{3} \mathrm{H}-3$-glucose into lipids measured as described by Moody et al. [14].

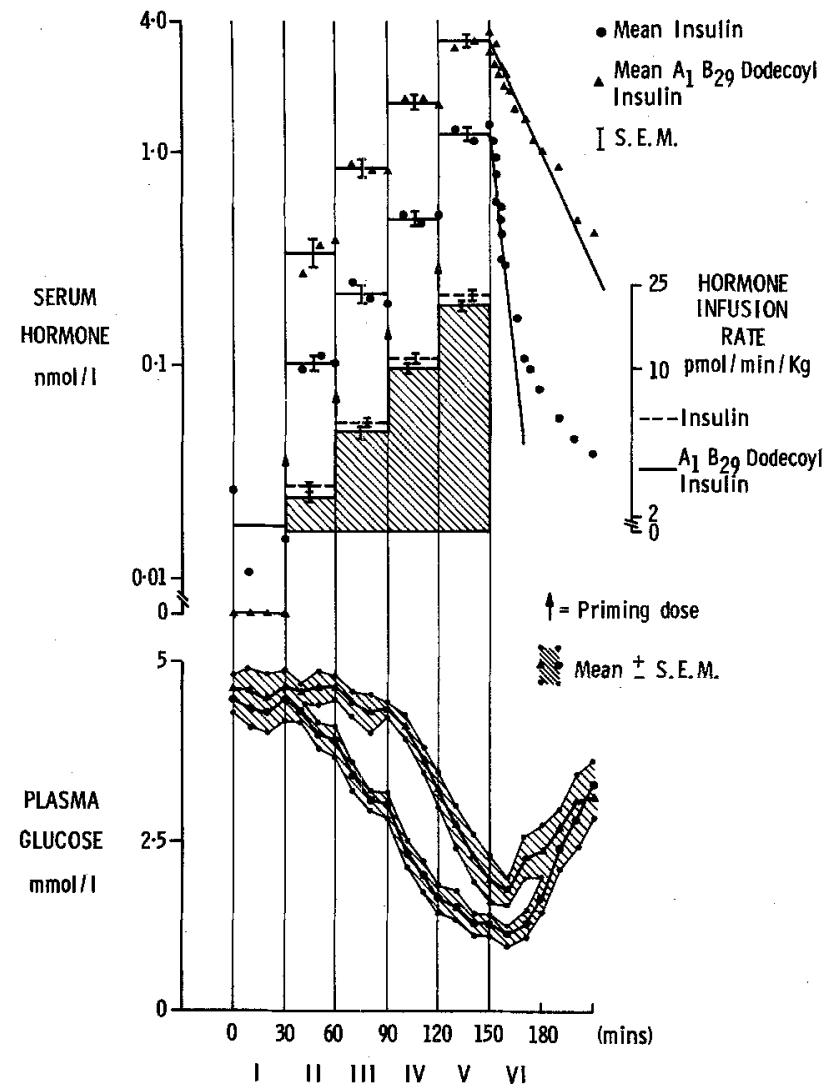

Fig. 2. Experimental design. (1) Each experiment was divided into six periods I-V of $30 \mathrm{~min}$ each, and VI of $90 \mathrm{~min}$. (2) Insulin or analogue was administered by continous infusion during periods II-V. The infusion rate was doubled at the end of each period. (3) Serum samples were estimated for insulin or analogue by radioimmunoassay. The diagram demonstrates the steady-state concentrations achieved during the infusion periods II to $V$ and the decay after the infusion was stopped. The reduced rate of metabolism of $\mathrm{A}_{1}-\mathrm{B}_{29}$ dodecoyl insulin is clearly demonstrated by the higher concentrations achieved and longer decay time. (4) Plasma glucose was measured throughout the experiments. The reduced hypoglycaemic activity of $A_{1}-B_{29}$ dodecoyl insulin can be seen

\section{Data Handling}

Estimates of the potency of proinsulin and analogues in relation to insulin were calculated in two ways. By the first method, hypoglycaemic activity was related to the total dose of material administered to the animal, and by the second, to the plasma concentration actually achieved.

\section{Method 1}

The fall from mean baseline plasma glucose concentration to the lowest value reached was taken as the measure of activity in each experiment and this was related to the total dose of material administered to the animal (Fig. 3). 

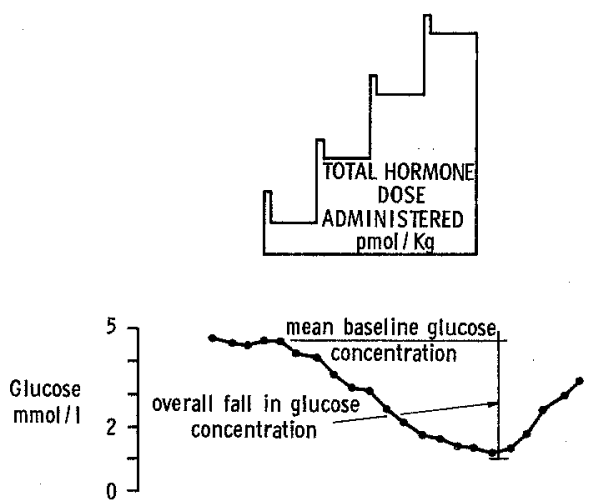

Fig. 3. Representation of dose-related method of bioassay calculation. The total dose of the hormone administered during the course of the experiment was related to the fall in glucose concentration from baseline to the lowest value achieved

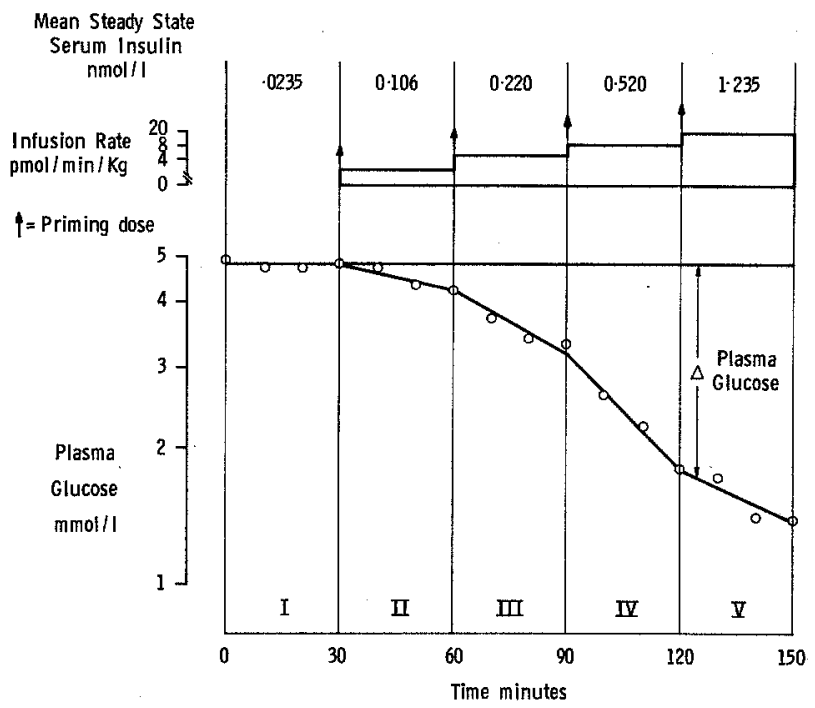

Fig. 4. Representation of concentration-related method of bioassay calculation. Plasma steady-state hormone concentration in each period was related to the fall in plasma glucose concentration from baseline to the value at the end of the relevant infusion period ( $\Delta$ plasma glucose)

Hypoglycaemic activity of the compound $=$ overall fall in plasma glucose $\mathrm{mmol} / \mathrm{l}$

dose of compound administered $\mathrm{pmol} / \mathrm{kg}$.

For each analogue the mean value obtained for this index has been expressed as a percentage of that of insulin. The unpaired $t$ test was used to test the significance of the difference of each analogue from insulin.

\section{Method 2}

For each experiment the plasma glucose concentration values were plotted on a semilog scale against time. A 'best fit' line was drawn through the points by eye. For each infusion period, the magnitude of the fall in glucose concentration from the mean baseline value, to the value at the end of the infusion was read from the graph, Figure 4. Thus each experiment provided four observations of activity which could be related to the four steady-state insulin or analogue concentrations. In some experiments the lower concentrations of insulin or analogue resulted in no measured fall in plasma glucose concentration, and, as is conventional in bioassays, such data points were excluded from the subsequent analysis.

These results were subjected to a parallel line bioassay analysis as described by Finney [15]. This technique tests the validity of the data as a bioassay by constructing dose-response curves and testing them for linearity, nonparallelism and heterogeneity of variance. If the required conditions are met, the potency of the analogue relative to insulin is calculated using a pooled slope, and from the variance of the data, $95 \%$ fiducial limits derived. As an example, the relationship between log dose and response is shown for insulin and $A_{1}, B_{29}$ diacetyl insulin in Figure 5.

This method of quantitating activity differs in one respect from more usual bioassay experiments in which each observation is entirely independent of all the others. As has been described above, from each experiment we derived four values for activity, one for each infusion period. These observations are to some extent mutually dependent. For example a steep fall during period II, the first infusion period, will not only give rise to a large value for bioactivity for that period but will also contribute a large value to the overall fall from baseline recorded for the subsequent infusion periods. In this way it could be argued that an inevitable and perhaps spurious linearity might be introduced into the data. In spite of this reservation, this method of approach to in vivo bioassay represents a considerable advance on the much cruder experiments previously performed.

Data from the fat cell experiments were processed by the same bioassay procedure (Finney [15]). All the analogues produced highly significant linear regression lines of response on $\log$-dose with no evidence of nonparallelism. Analogue potencies relative to insulin were derived from the horizontal distance between the regression lines fitted using a pooled slope.

\section{Results}

The results of assessing activity in relation to administered dose are shown in Table $1 . \mathrm{A}_{1}, \mathrm{~B}_{29}$ diacetyl insulin and two of the crosslinked analogues, $A_{1}-B_{29}$ suberoyl and $\mathrm{A}_{1}-\mathrm{B}_{29}$ dodecoyl insulins were not significantly different from insulin. $A_{1}-B_{29}$ oxalyl insulin 


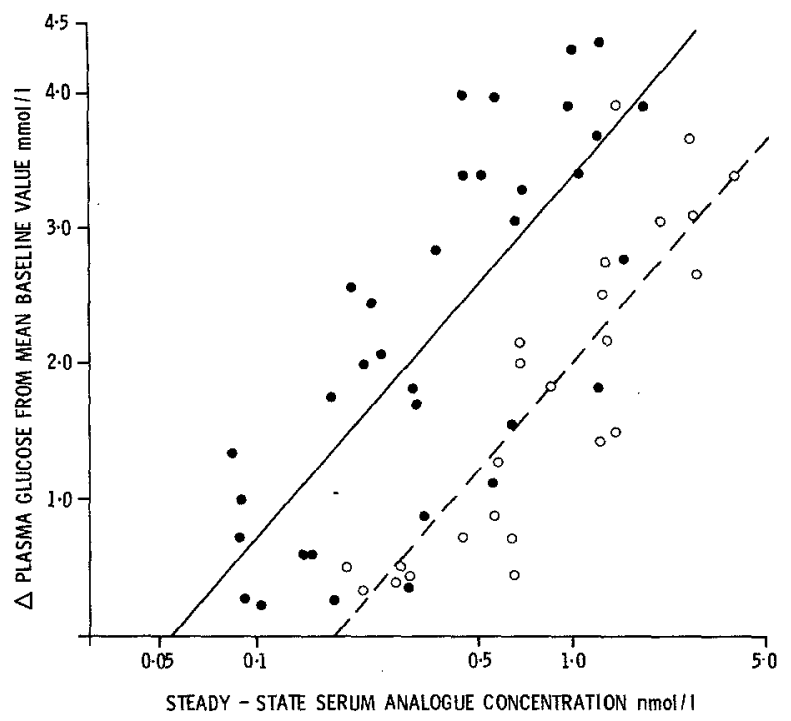

Fig. 5. $\log$ dose-response relationship for insulin $\bullet$, and for $A_{1}, B_{29}$ diacetyl insulin $O$ by the concentration-related method of calculation. Fitted lines for insulin - and $\mathrm{A}_{1}-\mathrm{B}_{29}$ diacetyl insulin --.-- as derived by the bioassay procedure described in the text are shown
Table 1. Results of potency estimations in relation to administered dose. Significance of difference from insulin estimated by the unpaired $t$ test. Results of Brandenburg et al. [5] and Lazarus et al. [6] are shown for comparison. N.S. = not significant

Dose related assays

\begin{tabular}{|c|c|c|c|}
\hline & Potency \% & $\mathrm{p}$ & $\begin{array}{l}\text { Brandenburg } \\
\text { et al. } \\
\text { Potency \% }\end{array}$ \\
\hline Insulin & 100 & & 100 \\
\hline $\mathrm{A}_{1}, \mathrm{~B}_{29}$ Diacetylinsulin & 97 & N.S. & 100 \\
\hline $\mathrm{A}_{1}-\mathrm{B}_{29}$ Oxalylinsulin & 29 & $<.01$ & 52 \\
\hline$A_{1}-B_{29}$ Suberoylinsulin & 63 & N. S. & 100 \\
\hline $\mathrm{A}_{1}-\mathrm{B}_{29}$ Dodecoylinsulin & 86 & N. S. & 46 \\
\hline Proinsulin & 50 & $<.01$ & $24^{a}$ \\
\hline
\end{tabular}

a Lazarus et al.

Table 2. Results of potency estimations in relation to analogue concentration. In vivo results are presented as mean potency with $95 \%$ fiducial limits, and fat cell results as mean and total range of observations. For the published results of Gliemann et al. [3,4] and Freychet et al. [2,24] shown for comparison, ranges where given represent $95 \%$ confidence limits, except $*=$ range obtained with three preparations

Concentration related assays

\begin{tabular}{lllll}
\hline & $\begin{array}{l}\text { In vivo } \\
\text { potency } \%\end{array}$ & $\begin{array}{l}\text { Fat cells, } \\
\text { potency } \%\end{array}$ & $\begin{array}{l}\text { Gliemann et al. } \\
\text { fat cells, potency } \%\end{array}$ & $\begin{array}{l}\text { Freychet et al. } \\
\text { liver membranc } \\
\text { binding affinity } \%\end{array}$ \\
\hline $\begin{array}{l}\text { Insulin } \\
\mathrm{A}_{1}-\mathrm{B}_{29} \text { Oxalylinsulin }\end{array}$ & 100 & 100 & 100 & 100 \\
$\mathrm{~A}_{1}-\mathrm{B}_{29}$ Suberoylinsulin & 5.2 & 4.5 & 3.7 & 1.1 \\
& $(2.7-10.3)$ & $(2.4-6.7)$ & $(2.6-4.8)$ & $(0.8-1.4)$ \\
$\mathrm{A}_{1}-\mathrm{B}_{29}$ Dodecoylinsulin & 6.9 & 5.6 & $(1.9-7.1)^{*}$ & $(1.2-1.8)$ \\
& $(3.4-14.0)$ & $(3.9-8.5)$ & 11.5 & $(1.9-2.7)$ \\
Proinsulin & 16.1 & 7.2 & $(10-13)$ & $3.5-4$ \\
$\mathrm{~A}_{1}, \mathrm{~B}_{29}$ Diacetylinsulin & $(10.0-25.8)$ & $(4.6-7.9)$ & 2 & 25 \\
& 5.0 & 2.3 & 28 & $(20-31)$ \\
\hline
\end{tabular}

had an activity of $29 \%$ that of insulin and proinsulin $50 \%$ that of insulin. For comparison, the reported in-vivo results for the semisynthetic materials (Brandenburg et al. [5]) and for proinsulin (Lazarus et al. [6]) are also shown in Table 1.

The potencies of the analogues as related to plasma concentrations are shown in Table 2 . They are compared with previously published data of Gliemann and Gammeltoft [3] and Gliemann and Sorensen [4] derived from an in vitro bioassay with isolated fat cells, and with results obtained in our own laboratory with a similar preparation. In addition, their relative binding affinities for liver cell membranes are also shown (Freychet [2]).

For $\mathrm{A}_{1}, \mathrm{~B}_{29}$ diacetyl insulin and the two crosslinked materials $A_{1}-B_{29}$ oxalyl and suberoyl insulins there is close agreement in the assays of biological activity. This is the first in vivo estimation that achieves this agreement and is the first that relates activity to prevailing plasma analogue concentration rather than to the administered dose. With proinsulin and $A_{1}-B_{29}$ dodecoyl insulin there is still some discre- 


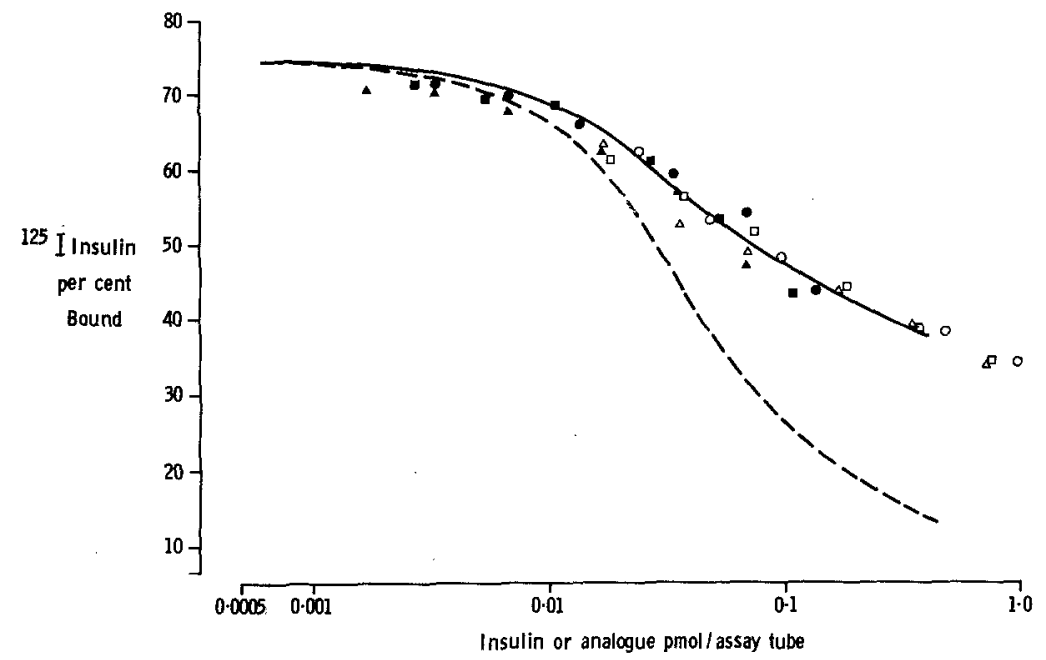

\begin{abstract}
Fig. 6. Radioimmunoassay results with $A b_{1}$ of serial dilutions of serum from 3 dogs undergoing experiments with $\mathrm{A}_{1}-\mathrm{B}_{29}$ dodecoyl insulin. Inhibition of ${ }^{125} \mathrm{I}$ insulin binding by increasing concentrations of bovine insulin -...., and of standard $\mathrm{A}_{1}-\mathrm{B}_{29}$ dodecoyl insulin _- and of serial dilutions of the following sera: $\operatorname{Dog} 1$ at the end of infusion period Vo; Dog 2 at the end of infusion period $V_{\triangle} ;$ Dog

3 at the end of infusion period $V \sqsubset ; \operatorname{Dog} 1$ $60 \mathrm{~min}$ after stopping infusion $\bullet ; \operatorname{Dog} 260$ min after stopping infusion $\wedge$; Dog $360 \mathrm{~min}$ after stopping infusion $\mathbf{m}$. The immunoreactive material in the sera is shown to resemble $\mathrm{A}_{1}-\mathrm{B}_{29}$ dodecoyl insulin and not bovine insulin
\end{abstract}

pancy in that the potencies in our in vivo experiments are slightly higher than those achieved with the fat cells.

Results of experiments using the discriminating antiserum $A b_{1}$ to assay immunoreactive material from dogs infused with $A_{1}-B_{29}$ dodecoyl insulin are shown in Figure 6.

Each sample in serial dilution is plotted on the graph in the appropriate position as indicated by assay with the non-discriminating antiserum GP5. It is clear that both the samples taken at the end of the infusion of the analogue, and $1 \mathrm{~h}$ after the infusion had ceased, behave immunoreactively in a way identical to standards of the original $\mathrm{A}_{1}-\mathrm{B}_{29}$ dodecoyl insulin, and not like standards of insulin. Therefore the suggestion that this analogue may be converted in vivo seems unlikely.

\section{Discussion}

There are a number of possible explanations for the observation that some insulin analogues are apparently more active in vivo than in vitro.

Lower rates of metabolism of these materials will result in a prolonged survival time and higher concentrations in plasma. In addition there is likely to be an effect on tissue sensitivity to a given plasma concentration. This is particularly true for tissues such as the liver which are not only responsive to insulin but also known to have a high capacity to degrade the hormone (Ansorge [16]).

In such tissues the concentration of the hormone at the receptor site will be determined not only by the concentration in plasma, but also by the rate at which the tissue is itself degrading it. For example, if insulin is very rapidly irreversibly removed by the degradative mechanisms, they will lower the hormone's con- centration at the cell surface to significantly below that in the plasma. On the other hand, with any given plasma concentration, an analogue that is more slowly metabolised will be present at a relatively higher concentration at the tissue receptors. This will remain true even if binding to the receptor sites is an essential prerequisite of degradation, as recently suggested by Terris and Steiner $[17,18]$.

For this effect to occur, an important assumption is that the vascular endothelium is sufficiently impermeable to insulin for an appreciable gradient to exist between the plasma and the interstitial fluid. Expressed alternatively, the apparent distribution space of insulin in vivo must be less than the extracellular volume. This assumption is supported by the observations of Sönksen et al. [11] who found both insulin and proinsulin to be distributed in a volume greater than that of the plasma, but smaller than the extracellular space.

Our second method of calculating bioactivity allows for the effect of metabolism on the plasma concentration, but does not correct for this latter effect on concentration at the cell surface. We have already shown in glucose turnover studies with these analogues that when compared to insulin, the crosslinked materials, especially proinsulin and $\mathrm{A}_{1}-\mathrm{B}_{29}$ dodecoyl insulin, have a proportionately greater effect in reducing glucose appearance from the liver than in stimulating peripheral glucose uptake in muscle and adipose tissue (C. V. Tompkins et al. [19]). Freychet's results [2], see Table 2, show that the binding affinity of these analogues for liver membranes is, if anything, less avid than would be expected from their bioactivity on the fat cell. Reduced local degradation in the liver, and proportionally higher concentrations at liver receptors in vivo would therefore satisfy Freychet's observations and our own on glucose turnover. It would also explain our observation 
that $\mathrm{A}_{1}-\mathrm{B}_{29}$ dodecoyl insulin and proinsulin have higher activites in our in vivo experiments than in isolated fat cells even after allowing for differences in plasma concentration.

The alternative suggestion that conversion of these materials to insulin takes place in vivo is effectively ruled out, at least for $\mathrm{A}_{1}-\mathrm{B}_{29}$ dodecoyl insulin, by the results presented in Figure 6 .

With $\mathrm{A}_{1}-\mathrm{B}_{29}$ oxalyl, $\mathrm{A}_{1}-\mathrm{B}_{29}$ suberoyl, and $\mathrm{A}_{1}, \mathrm{~B}_{29}$ diacetyl insulins the activities in vivo by the concentration related method of calculation compare very well with those of Gliemann [3, 4] and Freychet [2] and with our own data with isolated fat cells. We suggest therefore that quantitative differences in the metabolism of these materials compared to insulin explain adequately the discrepancies found in previous estimates of potency.

Clearly an experimental protocol such as ours, with a stepped infusion, does not allow a direct comparison with other in vivo data using a bolus technique, and perhaps this is reflected in the differences we find from Brandenburg, Puls et al. [5] (Table 1) who were also using a different species of animal.

It is of interest that the three semisynthetic crosslinked derivatives studied have markedly different biological activities. It is known that both $A_{1}$ glycine and $B_{29}$ lysine lie on the surface of the molecule and it has been suggested that this part of its structure is intimately concerned with binding to the receptor site (Blundell et al. [7]). Alternatively, Brandenburg et al. [5] have shown by circular dichroism studies that the addition of the $\mathrm{A}_{1}-\mathrm{B}_{29}$ crosslink does cause small conformational changes in the molecular structure in solution and it is possible that the reduced activity is caused by distortion of a binding site on the molecular surface which does not immediately involve the $\mathrm{A}_{1}-\mathrm{B}_{29}$ residues themselves. For example the Shanghai insulin research group [20] have presented evidence that the $B_{23}$ and $B_{24}$ amino acids are essential for activity and Wood et al. [21] and Pullen et al. [22] have also suggested that the area involving these residues may well constitute the active site, with the polar residues $\mathrm{A}_{1}, \mathrm{~A}_{4}, \mathrm{~A}_{19}$, and $\mathrm{A}_{21}$ at its periphery. They also have evidence that this area of the molecule is somewhat altered in conformation in $A_{1}$ modified derivatives (personal communication).

By whatever mechanism the crosslink between $A_{1}$ and $B_{29}$ interferes with activity it is perhaps not surprising that there should be an optimum distance between these two groups, so that crosslinks of different lengths will vary in the degree to which they impair function.

Glieman, Freychet and ourselves find $A_{1}-B_{29}$ dodecoyl insulin, with a chain length of 12 carbon atoms, has more activity than those with a shorter aliphatic bridge $[2,3,4]$. Brandenburg finds $A_{1}-B_{29}$ suberoyl insulin, with 8 carbon atoms in the crosslink, to be more active in vivo than either $A_{1}-B_{29}$ dodecoyl insulin or the more closely linked $A_{1}-B_{29}$ derivatives [5]. The distance between the $\mathrm{A}_{1} \alpha$ and $\mathrm{B}_{29} \varepsilon$ amino groups in the crystal is $1 \mathrm{~nm}$ [1], corresponding to the chain length of the suberoyl group [2]. However, in solution the side-arm of the $\mathrm{B}_{29}$ lysine is probably free to move relative to the rest of the molecule (Dodson, personal communication) and the crystallographic distance between these groups need not accurately indicate the distance between them when insulin is bound to the receptor.

With proinsulin, the position adopted by the Cpeptide and the basic amino-acids which attach it to the $A_{1}$ glycine and $B_{30}$ alanine groups has recently been studied by Snell and Smyth [23]. They suggest a conformation in which the C-peptide overlies and interacts with several of the surface structures in insulin which may well be involved in the active site. It is of interest that this natural crosslink between the $\mathrm{A}$ and $\mathrm{B}$ chains reduces biological activity to about $5 \%$ of that of insulin in the greyhound and to $2 \%$ in the rat fat cell. These results compare well with previous estimates of the activity of pork proinsulin in man, $5 \%$ Sönksen et al. [11] and with fat cells, 2\% Gliemann [4] and liver cell membranes, 3.5-4\% Freychet [24].

$\mathrm{A}_{1}, \mathrm{~B}_{29}$ diacetyl insulin shows a concentration related biological activity intermediate between that of the crosslinked materials, both natural (proinsulin) and semisynthetic, and that of insulin. This too is in support of the findings of Gliemann and Freychet.

Work with specifically chemically modified insulins is beginning to improve our understanding of the relationships between the biological properties of the insulin molecule and its structure. It is clear that there are highly specific structural requirements that have to be met not only for receptor binding and activation, but also if the molecule is to be susceptible to degradation. To understand the behaviour of an insulin antalogue in the whole animal it is clearly essential to study both the interactions with the receptor and the characteristics of its metabolism.

Acknowledgements. We are indebted to Dr. Schlichtkrull, Novo Research Laboratories, Copenhagen for donating pork proinsulin, to Dr. B. Hurn, Wellcome Research Laboratories, Beckenham, Kent for the gift of an antiinsulin antiserum and to Miss Alison McCreath for invaluable secretarial assistance. This research was supported by grants from the Wellcome Trust, The British Diabetic Association, and the Research (Endowments) Committee of St. Thomas' Hospital. M. J. Ellis was holder of a Commonwealth Postgraduate Scholarship in the United Kingdom. 
The chemical work was supported by the German Bundesministerium für Forschung und Technologie (Research project S. N. 1054).

\section{References}

1. Blundell, T. L., Dodson, G. G., Dodson, E., Hodgkin, D. C., Vijayan, M.: X-ray analysis and the structure of insulin. Recent Progr. Hormone Res. 27, 1-40 (1971)

2. Freychet, P., Brandenburg, D., Wollmer, A.: Receptor-binding assay of chemically modified insulins. (Comparison of in vitro and in vivo bioassays). Diabetologia 10, 1-5 (1974)

3. Gliemann, J., Gammeltoft, S.: The biological activity and the binding affinity of modified insulins determined on isolated fat cells. Diabetologia 10, 105-113 (1974)

4. Gliemann, J., Sørensen, H. H.: Assay of insulin-like activity by the isolated fat cell method. IV. The biological activity of proinsulin. Diabetologia 6, 499-504 (1970)

5. Brandenburg, D., Busse, W., Gattner, H., Zahn, H., Wollmer, A., Gliemann, J., Puls, W.: Structure-function studies with chemically modified insulins. Peptides 72: Proceedings of the Twelfth European Peptide Symposium, Reinhardsbrunn Castle, German Democratic Republic. September 1972, pp. 270-283. Amsterdam: North-Holland Publishing Company 1973

6. Lazarus, N. R., Penhos, J. C., Tanese, T., Michaels, L., Gutman, R., Recant, L.: Studies on the biological activity of porcine proinsulin. J. clin. Invest. 49, 487-496 (1970)

7. Blundell, T., Dodson, G., Hodgkin, D., Mercola, D.: Insulin, the structure in the crystal and its reflection in chemistry and biology. Advanc Protein Chem. 26, 279-402 (1972)

8. Brandenburg, D.: Preparation of $\mathrm{N}^{\alpha A}, \mathrm{~N}^{\mp} \mathrm{B}_{29}$ adipoylinsulin, an intramolecularly crosslinked derivative of beef insulin. HoppeSeylers Z. physiol. Chem. 353, 869-873 (1972)

9. Brandenburg, D., Gattner, H. G., Wollmer, A.: Darstellung und Eigenschaften von Acetylderivaten des Rinderinsulins. I. Hoppe-Seylers Z. physiol. Chem. 353, 599-617 (1972)

10. Morgan, C. R., Lazarow, A.: Immunoassay of insulin. Two antibody system plasma insulin levels of normal, subdiabetic and diabetic rats. Diabetes 12, 115-126 (1963)

11. Sönksen, P.H., Tompkins, C. V., Srivastava, M. C., Nabarro, J. D. N.: A comparative study on the metabolism of human insulin and porcine proinsulin in man. Clin. Sci. 45, 633-654 (1973)

12. Greenwood, F. C., Hunter, W. M., Glover, J. S.: The preparation of ${ }^{131}$-I-labelled human growth hormone of high specific radioactivity. Biochem. J. 89, 114-123 (1963)
13. Gliemann, J.: Assay of insulin-like activity by the isolated fat cell method. I. Factors influencing the response to crystalline insulin. Horm. Metab. Res. 6, 12-16 (1964)

14. Moody, A. J., Stan, M. A., Stan, M., Gliemann, J.: A simple free fat cell bioassay for insulin. Horm. Metab. Res. 6, 12-16(1964)

15. Finney, D. J.: Statistical methods in biological assay. Second Edition, pp. 99-138. London: Griffin 1964

16. Ansorge, S., Bohley, P., Kirshke, H., Langner, J., Hanson, H.: Metabolism of insulin and glucagon. Breakdown of radioinodinated insulin and glucagon in rat liver cell fractions. Europ. J. Biochem. 19, 283-288 (1971)

17. Terris, S., Steiner, D. F.: Binding and degradation of ${ }^{125} I$-insulin by rat hepatocytes. J. biol. Chem. 250, 8389-8398 (1975)

18. Terris, S., Steiner, D. F.: Retention and degradation of ${ }^{125} \mathrm{I}$-insulin by perfused livers from diabetic rats. J. clin. Invest. 57, 885-896 (1976)

19. Tompkins, C. V., Sönksen, P. H., Jones, R. H.: Structural modifications to the insulin molecule and their effects on glucose metabolism. J. Endocr. 65, 59 (1975)

20. The Shanghai Insulin Research Group: Studies on the structure-function relationships of insulin. I. The relationship of the C-terminal peptide sequence of B-chain to the activity of insulin. Scientia Sinica 16, 61-70 (1973)

21. Wood, S. P., Blundell, T. C., Wollmer, A., Lazarus, R., Neville, R. W. J.: The relation of conformation and association of insulin to receptor binding: X-ray and circular dichroism studies on bovine and hystricomorph insulins. Europ. J. Biochem. 55, 531-542 (1975)

22. Pullen, R. A., Lindsay, D. G., Wood, S. P., Tickle, I. J., Blundell, T. L., Wollmer, A., Krail, G., Brandenburg, D., Zahn, H., Gliemann, J., Gammeltoft, S.: Receptor-binding region of insulin. Nature 259, 369-373 (1976)

23. Snell, C. R., Smyth, D. G.: Proinsulin - a proposed three dimensional structure. J. biol. Chem. 250, 6291-6295 (1975)

24. Freychet, P.: The interactions of proinsulin with insulin receptors on the plasma membrane of the liver. J. clin. Invest. 54, 1020-1031 (1974)

Received: February 26, 1976, and in revised form: August 3, 1976

Dr. R. H. Jones

Lecturer in Medicine

Dept. of Medicine

St. Thomas's Hospital Medical School

London, SE 1 7EH

England 